in the presentation of the subject. Of course, in some sense and to some extent it is and must be true. Whatever is special, accidental, and individual, will die, as it should; but that which is universal and essential should remain as an organic part of the whole intellectual acquisition. If that which is essential dies with the accidental, it must be because the accidental has been given the prominence which belongs to the essential. For myself, I should preach no such doctrine to those whom I wish to convert to the true faith.

In Italy, they say, all roads lead to Rome. In mechanics, kinematics, astronomy, physics, all study leads to the considera tion of certain relations and operations. These are the capital notions; these should have the leading parts in any analysis suited to the subject.

If I wished to attract the student of any of these sciences to an algebra for vectors, I should tell him that the fundamerital notions of this algebra were exactly those with which he was daily conversant. I should tell him that a vector algebra is so far from being any one man's production that half a century ago several were already working toward an algebra which should be primarily geometrical and not arithmetical, and that there is a remarkable similarity in the results to which these efforts led (see Proc. A.A.A.S. for 1886 , pp. 37, ff.). I should call his attention to the fact that Lagrange and Gauss used the notation $(\alpha \beta \gamma)$ to denote precisely the same as Hamilton by his $\mathrm{S}(\alpha \beta \gamma)$, except that Lagrange limited the expression to unit vectors, and Gauss to vectors of which the length is the secant of the latitude, and I should show him that we have only to give up these limitations, and the expression (in connection with the notion of geometrical addition) is endowed with an immense wealth of transformations. I should call his attention to the fact that the notation $\left[r_{1} r_{2}\right]$, universal in the theory of orbits, is identical with Hamilton's $V\left(\rho_{1} p_{2}\right)$, except that Hanilton takes the area as a vector, i.e. includes the notion of the direction of the normal to the plane of the triangle, and that with this simple modification (and with the notion of geometrical addition of surfaces as well as of lines) this expression becomes closely connected with the first-mentioned, and is not only endowed witl a similar capability for transformation, but enriches the first with new capabilities. In fact, I should tell him that the notions which we use in vector analysis are those which he who reads between the lines will meet on every page of the great masters of analysis, or of those who have probed deepest the secrets of nature, the only difference being that the vector analyst, having regard to the weakness of the human intellect, does as the early painters who wrote beneath their pictures "This is a tree," "This is a horse."

I cannot attach quite so much importance as Mr. McAulay to uniformity of notation. That very uniformity, if it existed among those who use a vector analysis, would rather obscure than reveal their connection with the general course of modern thought in mathematics and physics. There are two ways in which we may measure the progress of any reform. The one consists in counting those who have adopted the shibboleth of the reformers; the other measure is the degree in which the community is imbued with the essential principles of the reform. I should apply the broader measture to the present case, and do not find it quite so bad as $\mathrm{Mr}$. McAulay does.

Yet the question of notations, although not the vital question, is certainly important, and I assure Mr. McAulay that reluctance to make unnecessary innovations in notation has been a very powerful motive in restraining me from publication. Indeed my pamphlet on "Vector Analysis," which has excited the animadversion of quaternionists, was never formally published, although rather widely distributed, so long as I had copies to distribute, among those who I thought might be interested in the subject. I may say, however, since I am called upon to defend my position, that I have found the notations of that pamphlet more flexible than those generally used. Mr. McAulay, at least, will understand what I mean by this, if I say that some of the relations which he has thought of sufficient importance to express by means of special devices (see Proc. R. S. E., for I890-91), may be expressed at least as briefly in the notation which I have used, and without special devices. But I should not have been satisfied for the purposes of my pamphlet with any notation which should suggest even to the careless reader any connection with the notion of the quaternion. For I confess that one of my objects was to show that a system of vector analysis does not require any support from the notion of the quaternion, or, I may add, of the imaginary in algebra. NO. 1220 , vOL. 47
I should hardly dare to express myself with so much freedom, if I could not shelter myself behind an authority which will not be questioned.

I do not see that I have done anything very different from what the eminent mathematician upon whom Hamilton's mantle has fallen has been doing, it would seem, unconsciously. Contrast the system of quaternions, which he has described in his sketch of Hamilton's life and work in the North British Reviezv for September, 1866, with the system which he urges upon the attention of physicists in the Philosophical Magazine in 1890 . In 1866 we have a great deal about imaginaries, and nearly as much about the quaternion. In 1890 we have nothing about imaginaries, and little about the quaternion. Prof. Tait has spoken of the calculus of quaternions as throwing off in the course of years its early Cartesian trammels. I wonder that he does not see how well the progress in which he has led may be described as throwing off the yoke of the quaternion. A characteristic example is seen in the use of the symbol $\nabla$. Hamilton applies this to a vector to form a quaternion, Tait to form a linear vector function. But while breathing a new lift into the formule of quaternions, Prof. Tait stands stoutly by the letter.

Now I appreciate and admire the generous loyalty toward one whom he regards as his master, which has always led Prof. Tait to minimise the originality of his own work in regard to quaternions, and write as if everything was contained in the ideas which flashed into the mind of Hamilton at the classic Brougham Bridge. But not to speak of other claims of historical justice, we owe duties to our scholars as well as to our teachers, and the world is too large, and the current of modern thought is too broad, to be confined by the ipse dixit even of a Hamilton.

$$
\text { J. Willard Gibiss. }
$$

\section{Glacial Drift of the Irish Channel.}

Ir seems of interest to record that the eurite or microgranite containing blue amphibole (Riebeckite), the rock noticed by Mr. P. F. Kendall in the drifts of the Isle of Man and Caernarvonshire, occurs abundantly in the form of small pebbles on the shore at Killiney, co. Dublin, doubtless derived from the "glacial gravels" of the coast. I have also found a pebble in the raised beach at Greenore, co. Down.

Mr. Teall's description of the rock of Ailsa Craig (Mineralogical Magazine, vol. ix. p. 219) enabled the very characteristic pebbles collected by $\mathrm{Mr}$. Kendall to be referred to that mass as a source, or to formerly existing bosses south of or adjacent to it. As far as I am aware, all the material is in the form of pebbles, often only an inch in diameter. This is hardly likely to be its original condition, if removed by ice from Ailsa Craig, and is only one of many points that indicate a redistribution of our socalled "glacial" beds by subsequent action of rivers or other waters. Grenville A. J. Colf.

Royal College of Science for Ireland, Dublin, March I 2.

\section{THE SACRED NILE.}

THAT Egypt is the gift of the Nile is a remark we owe to the father of history, who referred not only to the fertilising influence of the stream, but to the fact that the presence of the Nile and its phenomena are the conditions upon which the habitability of Egypt altogether depends. That that part of Egyptian archæology and myth which chiefly interests astronomers is also the gift of the Nile is equally true.

The heliacal rising of Sirius and other stars at the time of the commencement of the inundations each year; all the myths which grew out of the various symbols of the stars so used, are so many evidences of the large share the river, with its various water levels at different times, had in the national life. It was, in fact, the true and unique basis of the national life.

In this the Nile had a compeer, or even compeers. What the Nile was to Egypt the Euphrates and Tigris were to a large region of Western Asia, where also we find the annual flood to have been in ancient times a source of fertility over an enormous area which is now 
desert, the plains being broken by the remains of the ancient canals.

What more natural than that Euphrates, Tigris and Nile were looked upon as deities; that the Gods of the Nile valley on the one hand, and of the region watered by the Euphrates and Tigris on the other, were gods to swear by; that they were worshipped in order that their benign influences might be secured, and that they had their local shrines and special cults.

The god sacred to the Euphrates and Tigris was called Ea. The god sacred to the Nile was called Hapi.

The name Hapi is the same as that of the bull Apis, the worship of which was attributed to Mena. ${ }^{1}$ Certainly Mena, Mini, or Menes, as he is variously called, was fully justified in founding the cult of the river god, for he first among men appears to have had just ideas of irrigation; and I have heard the distinguished officers who have lately been responsible for the irrigation system of to-day speaking with admiration of the ideas and works of Menes.

Whether the Tigris had a Menes in an equally early time is a point on which history is silent; but, according to the accounts of travellers, the Tigris in flood is even more majestic than the Nile, and yet the latter river in flood is a sight to see-a whole fertile plain turned into, as it were, an arm of the sea, with here and there an island, which on inspection turns out to be a village, the mud houses of which too often are undermined by the lapping of the waves in the strong north wind.

There is no doubt that the dates of the rise of these rivers not only influenced the national life but even the religions of the dwellers on their banks. The Euphrates and Tigris rise about the time of the spring equinox-the religion was equinoxial, the temples were directed to the east. The Nile rises at a solstice - the religion was solstical and the solar temples were directed no longer to the east. To the Egyptians the coming of the river to the parched land was as the sunrise chasing the darkness of the night; the sun-god of day conquering the stargods of night; or again the victorious king of the land slaughtering his enemies.

By no one, perhaps, have the impressions produced by the various phases of the river been so poetically described as by Osburn, a writer of vivid imagination, but it must be added that the facts detailed in his description are not exactly capable of being verified by engineering science. Osburn thus describes the low Nile :

"The Nile has shrunk within its banks until its stream is contracted to half its ordinary dimensions, and its turbid, slimy, stagnant waters scarcely seem to flow in any direction. Broad flats or steep banks of black, sunbaked Nile mud, form both the shores of the river. All beyond them is sand and sterility; for the hamseen, or sand-wind of fifty days' duration, has scarcely yet ceased to blow. The trunks and branches of trees may be seen here and there through the dusty, hazy, burning, atmosphere, but so entirely are their leaves coated with dust, that at a distance they are not distinguishable from the desert sand that surrounds them. It is only by the most painful and laborious operation of watering that any tint approximating to greenness can be preserved at this season even in the pleasure-gardens of the Pacha. The first symptom of the termination of this most terrible season is the rising of the north wind (the Etesian wind of the Greeks), blowing briskly, often fiercely during the whole of the day. The foliage of the groves that cover Lower Egypt is soon disencumbered by it of the dust, and resumes its verdure. The fierce fervours of the sun, then at his highest ascension, are also most seasonably mitigated by the same powerful agency, which prevails for this and the three following month's throughout the entire land of Egypt."

$$
\text { I Maspero, "Hist. Anc." xi. } 10 .
$$

Then at last comes the inundation:-

"Perhaps there is not in Nature a more exhilarating sight, or one more strongly exciting to confidence in God, than the rise of the Nile. Day by day and night by night, its turbid tide sweeps on ward majestically over the parched sands of the waste, howling wilderness. Almost hourly, as we slowly ascended it before the Etesian wind, we heard the thundering fall of some mud-bank, and saw by the rush of all animated Nature to the spot, that the Nile had overleapt another obstruction, and that its bounding waters were diffusing life and joy through another desert. There are few impressions I ever received upon the remembrance of which I dwell with more pleasure than that of seeing the first burst of the Nile into one of the great channels of its annual overflow. All Nature shouts for joy. The men, the children, the buffaloes, gambol in its refreshing waters, the broad waves sparkle with shoals of fish, and fowl of every wing flutter over them in clouds. Nor is this jubilee of Nature confined to the higher orders of creation. The moment the sand becomes moistened by the approach of the fertilising waters, it is literally alive with insects innumerable. It is impossible to stand by the side of one of these noble streams, to see it every moment sweeping away some obstruction to its majestic course, and widening as it flows, without feeling the heart to expand with love and joy and confidence in the great Author of this annual miracle of mercy."

The effects of the inundation, as Osburn shows in another place, "exhibit themselves in a scene of fertility and beauty such as will scarcely be found in another country at any season of the year. The vivid green of the springing corn, the groves of pomegranate trees ablaze with the rich scarlet of their blossoms, the fresh breeze laden with the perfumes of gardens of roses and orange thickets, every tree and every shrub covered with sweet-scented flowers. These are a few of the natural beauties that welcome the stranger to the land of Ham. There is considerable sameness in them, it is true, for he would observe little variety in the trees and plants, whether he first entered Egypt by the gardens of Alexandria or the plain of Assouan. Yet is it the same everywhere, only because it would be impossible to make any addition to the sweetness of the odours, the brilliancy of the colours, or the exquisite beauty of the many forms of vegetable life, in the midst of which he wanders. It is monotonous, but it is the monotony of Paradise."

"The flood reaches Cairo on a day closely approximating to that of the summer solstice. It attains its greatest height, and begins to decline near the autumnal equinox. By the winter solstice the Nile has again subsided within its banks and resumed its blue colour. Seed-time has occurred in this interval. The year in Egypt divides itself into three seasons--four months of sowing and growth, corresponding nearly with our November, December, January, and February; four months of harvest from March to June ; the four months of the inundation completing the cycle."

In order to show how the astronomy of the ancient Egyptians--to deal specially with them-was to a large extent concerned with the annual flood and all that depended upon that flood, and how the first solar year used on this planet, so far as we know, was established, it is important to study the actual facts of the rise somewhat closely, not only for Egypt generally, but for several points in the line some thousand miles in extent, along which in the earliest times cities and shrines were dotted here and there.

Time out of mind the fluctuations in the height of the river have been carefully recorded at different points along the river. In the "Description de l'Egypt" we find a full description of the so-called nilometer at Assuan (First Cataract) which dates from a remote period, perhaps as early as the 5 th Dynasty.

In Ebers' delightful book on Egypt space is given to

No. I 220 , vol. 47 ] 
the description of the much more modern one located at Rodah.

The nilometer, or "mikyas," on the island of Rodah now visible, is stated to have replaced one which was brought thither from Memphis at some unrecorded date. Makreezee in 1417 , according to Ebers, saw the remains of the older nilometer.

The present mikyas is within a covered vault or chamber, the roof being supported on simple wooden pillars. In a quadrangular tank communicating with the river by a canal is an octagon pillar on which the Arabic measurements are inscribed. These consist of the pic (variously called ell or cubit) $=0.54$ metre, which is divided into twenty-four kirats, in consequence of the rise of the river bed in relatively recent times, the nilometer is submerged at high Nile to a depth of two cubits.

The rise of the Nile can now be carefully studied, as gauges are distributed along the river. We have the Aswân gauge from I869, the Armant gauge from 1887, the Suhag gauge from 1889 , and the Asyût gauge from I882. The distances of these gauges from Aswân are as follows :-

\begin{tabular}{lccccc} 
& & & & \multicolumn{2}{c}{ Kilometres } \\
Aswân & $\ldots$ & $\ldots$ & $\ldots$ & $\ldots$ & 0 \\
Armant & $\ldots$ & $\ldots$ & $\ldots$ & $\ldots$ & 200 \\
Suhag $\ldots$ & $\ldots$ & $\ldots$ & $\ldots$ & $\ldots$ & 447 \\
Asyût $\ldots$ & $\ldots$ & $\ldots$ & $\ldots$ & $\ldots$ & 550 \\
Rodah $\ldots$ & $\ldots$ & $\ldots$ & $\ldots$ & $\ldots$ & 94 I
\end{tabular}

The Rodah gauge is not to be depended on as the movements of the Barrage regulation destroy its value as a record. The heights of the zeros of these gauges above mean sea level are as follows :-

$\begin{array}{llllll}\text { Aswân } & \ldots & \ldots & \ldots & \ldots & 84.158 \\ \text { Armant } & \ldots & \ldots & \ldots & \ldots & 69.535 \\ \text { Suhag } & \ldots & \ldots & \ldots & \ldots & 56.00 \\ \text { Asyut } & \ldots & \ldots & \ldots & \ldots & 53.10 \\ \text { Rodah } & \ldots & \ldots & \ldots & \ldots & 13.14\end{array}$

Great vagueness arises in there being no very obvious distinction between the gauge readings reached in summer and that from which the rise is continuous. There are apparently rainfalls in the end of spring of sufficient power to raise the Nile visibly in summer, just as muddy rises have been seen in winter to pass down the valley, leaving a muddy mark on the rocks at Aswân and Manfalût. Independently of the actual gauge-reading of the rise, there are facts about it which strike every beholder. At the commencement of the rise we have the green water. This occurs in June, but varies in date as much as the top of the fiood varies.

From the fact that modern observations show that the very beginning of the rise, and the first flush, second flush, and final retirement vary, it seems evident that the ancient Egyptians could not have had any fixed zero-gauge or time for the real physical fact of the rise, but must have either deduced from a series of observations a mean period of commencement, or a mean arrival of the red water, or a mean rising up to a certain gauge.

First to deal with the green water. Generally when the rise of an inch or two is reported from the nilometer at Rodah, the waters lose the little of clearness and freshness they still possessed. The green colour is the lustreless hue of brackish water within the tropics, and only the finer class of modern filter can render such water clear. The colour is really due to algæ.

Happily, the continuance of this state of the water seldom exceeds three or four days. The sufferings of those who are compelled to drink it in this state, from vesicary disease, even in this short interval, are very severe. The inhabitants of the cities generally provide against it by Nile-water stored in reservoirs and tanks.

Col. Ross, R.E., noticed in 1887 and in 1890 , when, owing to the slow retreat of the Nile, the irrigation officers had to hold back many basins in the Gizah province; and also in 1888 , when the water remained long stagnant that the basin-water got green-showed the alga and smelt marshy, just as the June green water does.

Hence it has been argued that as the Nile-water in the bed of the stream-even in very slow-flowing back-waters - does not become green, the greenness must be produced by an almost absolute stagnation of the water. We know of great marshes up above Gondokoro, and hence it is thought that the green water of summer, which comes on suddenly, is this marsh-water being pusbed out by the new water from behind, and that is why it heralds the rise. No one has so far minutely observed the gradual intrusion of the green water.

The rise of the river proceeds rapidly, and the water gradually becomes more turbid. Ten or twelve days, however, elapse before the development of the last and most extraordinary of all the appearances of the Nile, thus described by Mr. Osborn ${ }^{1}$ :- "It was at the end of -to my own sensations-a long and very sultry night, that I raised myself from the sofa upon which $I$ had in vain been endeavouring to sleep, on the deck of a Nile boat that lay becalmed off Benisoueff, a town of Middle Egypt.

"The sun was just showing the upper limb of his disc over the eastern mountains. I was surprised to see that when his rays fell upon the water, a deep ruddy reflection was given back. The depth of the tint increased continually as a larger portion of his light fell upon the water, and before he had entirely cleared the top of the hill it presented the perfect appearance or a river of blood. Suspecting some delusion, I rose up hastily, and looking over the side of the boat saw there the confirmation of my first impression. The entire body of the water was opaque and of a deep red colour, bearing a closer resemblance to blood than to any other natural production to which it could be compared. I now perceived that during the night the river had visibly risen several inches. While I was gazing at this great sight, the Arabs came round me to explain that it was the Red Nile. The redness and opacity of the water, in this extraordinary condition of the river, are subject to constant variations. On some days, when the rise of the river has not exceeded an inch or two, its waters return to a state of semi-transparency, though during the entire period of the high Nile they never lose the deep red tinge which cannot be separated from them. It is not, however, like the green admixture, at all deleterious; the Nile water is never more wholesome or more deliciously refreshing than during the overflow. There are other days when the rise of the river is much more rapid, and then the quantity of mud that is suspended in the water exceeds, in Upper Egypt, that which $I$ have seen in any other river. On more than one occasion I could perceive that it visibly interfered with the flow of the stream. A glassful of it in this state was allowed to remain still for a short time. The upper portion of it was perfectly opaque and the colour of blood. A sediment of black mud occupied about one quarter of the glass. A considerable portion of this is deposited before the river reaches Middle and Lower Egypt. I never observed the Nile water in this condition there, and indeed no consecutive observations exist of the reddening of the water. It is quite clear that the reddening cannot come from the White Nile, but must be the first floods of the Blue Nile and the Atbara coming down."

Rate of Rise of the Nile.-The rate in flood is $1 \frac{3}{4}$ days from Wady Halfa to Aswân and six days from Aswân to Rodah (94I kilometres). In very high Niles this is perhaps accelerated to five days. In the early flood rising from, say, one cubit Aswân to six cubits, where there are many dry sandbanks, and the spreading out of the river is considerable, and there is an absence of overlapping

\footnotetext{
I "Monumental Egypt," chapter i.
}

NO. I 220 , VOL. 47] 
flushes from behind, the rate goes up to fifteen days. There is a very great difference in time and rate between Green and Red Nile. The rise is $45 \mathrm{ft}$. at Aswân, 38 at Thebes, and 25 at Cairo.

From the data obtained at the gauges named which have been kindly forwarded to me by Mr. Garstin, the U.S. of State of the Public Works Department of Egypt, I have ascertained that the average time taken by the flood to travel now between Thebes and Memphis is about nine days. Although the river bed is now higher than formerly, the land around Thebes, according to Budge, having been raised about nine feet in the last 1700 years, still the same elevation has taken place at Memphis, so that no difference in the velocity of the stream would be produced by this cause.

The great difficulty experienced in understanding the statements generally made concerning the Nile-rise arises from the fact that the maximum flood is as a rule registered in Cairo upwards of 40 days after the maximum of Aswân.

For the following account of how this is brought about I am indebted to the kindness of Col. Ross, R.E. :-

"The behaviour of the flood at the Aswân gauge is as follows: Between August 20 and 30 a good average gauge of 16 cubits is often reached, and between August 27 and September 3 there is often a drop of about 30 centimetres. The August rise is supposed to be mostly due to the Blue Nile and Atbara River. Between September $I$ and 8 the irrigation officers generally look for a maximum flood-gauge of the year at Aswân. This is supposed to be the first flush of the White Nile. In the middle of September there are generally two small flushes, but the last twenty days of September are generally distinctly lower than that of the first week. The final flush of the Nile is seldom later than the 2 rst to 25 th September.

"All this water does not merely go down the Nile; it floods the different basins. The opening of these basins begins from the south to the north. This operation is generally performed between the 2 th September and the 22nd October. The great Central Egypt basins are not connected with the Nile for purposes of discharge into the river between Asyût and near Wasta, or a distance of $395-90$ kilometres $=305$ kil.

"The country in the middle or Central Egypt is broad, and thus there is an enormous quantity of water poured out of these basins into the lower reaches of the river about the 2oth October, which seriously raises the Nile at Cairo, and in a good average year will bring the Cairo gauge (at Rodah) up to the maximum of the year on or about October 22, and hence it is that the guide books say the Nile is at its highest in the end of Uctober.

"A gauge of $16 \frac{1}{2}$ cubits at Aswân while the basins are being filled does not give more than 21 cubits at Rodah (Cairo), but as the basins with a $16 \frac{1}{2}$ gauge will fill by the Ioth September, it follows that a $16 \frac{1}{2}$ to 16 cubit gauge at Aswân will not give a constant Cairo gauge, as the great mass of water passes by the basins and reaches Cairo. Hence we have frequently the paradox of a steady or falling gauge at Aswân showing a steady rise at Cairo.

"It the gauge at Aswân keeps above 16 cubits to near the end of September, the basin-emptying is much retarded, as the emptying at each successive basin fills the Nile above the 16 cubit level; hence the lower halves of the chains of basins do not flow off, and thus when the great Middle Egypt basins are discharged, they do not raise the Nile so much as they do when the last half of September Nile is below 16 at Aswân.

"In years like $188 \%$ and 1892 , which differ from each other only in date of maximum gauge at Aswân, the river, having filled the basins in 15 to 20 days instead of in 25 to 30 days, comes down to Cairo in so largely increased a volume that a really dangerous gauge of 25 cubits at Cairo is maintained for over a fortnight (the average October gauge in Cairo is about 23 cubits), and from September Io to October 25 the river remains from 24 cubits to $25^{\frac{1}{2}}$ cubits, and the Middle Egypt basins discharge so slowly that the opening day is hardly traceable on the Cairo gauge.

"In the I 878 flood, which was the most disastrous flood possible, the river rose in the most abnormal fashion, and on October 3 attained 18 cubits at Aswân. This breached the Delta, and in addition so delayed the Upper Egypt basins emptying from the reason before given that the wheat was sown too late, and got badly scorched by the hot winds of March and April."

J. NORMAN LOCKYER.

\section{THE LANDSLIP AT SANDGATE.}

THE causes of landslips are in general so well known and the localities which are liable to them so clearly defined on geological principles that when on Monday, March 6, the public were startled by the news of a landslip at Sandgate, the probability would be that geologists who knew the district would be by no means surprised, more particularly as the locality of the catastrophe is in the midst of a typical section shown in many of the textbooks, and the town itself gives its name to a subdivision of the Cretaceous rocks.

The event, however, does not appear to have been expected, and since it has happened conjectures as to its cause have been numerous; but the true explanation has been wanting.

The series of rocks which, in descending order, form the country about Sandgate are the Folkestone beds, the Sandgate beds, the Hythe beds, and the Atherfield clay. Amongst these it is natural to look in the first instance for the presence of clays, as the probable origin of a landslip, though very loose sands have also been known to give way. The Folkestone beds are for the most part sand and they are bound together by bands of grit. Moreover, they are above the affected area. The Hythe beds are likewise characterised by bands of hard limestone, separated by calcareous sands. There are left the Atherfield clay, whose nature is indicated by its name, and the Sandgate beds.

The most recent description of these is that of W. Topley, F.R.S., in the Comptes Rendus of the Congrès Géologique International, I 888 , in which they are briefly characterised (p. 257) as "Argiles vertes et sables." The same writer's description of them in 1883 (quoted also by H. B. Woodward in 1887 ) is somewhat different, but in his "Geology of the Weald," I 875 , they are said to consist of dark clayey sand and clay, the total thickness being given as $80 \mathrm{ft}$. In his more detailed description, however, $\mathrm{Mr}$. F. G. H. Price divides these $80 \mathrm{ft}$. into four parts, the lowest $20 \mathrm{ft}$. being all " clayey beds" (Proc. Geol. Assoc., vol. iv. p. 554). In a still earlier account by Prof. Morris (l.c. vol. ii. p. 4I) we have the following interesting statement:"The dark-greenish sub-argillaceous sands, known as the Sandgate beds, rise on the shore at a short distance west of Folkestone. The low undercliff which skirts the shore from Folkestone nearly to Hythe owes its origin to the presence of these beds, which from their retention of water and slight coherency of structure have caused the frequent subsidence of the beds above."

It would appear, then, that there are two possible sources of the slipping-the Atherfield clay and the clayey bands of the Sandgate beds, and thus much was indicated at once by Mr. F. W. Rudler (Daily Graphic, March 8).

On a personal examination of the area the whole history of the subsidence becomes clear enough. At

The modern Egyptians still hold to the old months for irrigation. 7 Tuba = January 15 is commencement of wheat irrigation; 30 Misra is the last safe date for sowing maize in the Delta ; Ist ' $T$ ut is the date of regulating the bridges=September 8 in Upper Egypt.

NO. I 220 , VOL. 47] 